\title{
Plasmaferesis Sebagai Terapi Sindrom Guillain-Barre Berat pada Anak
}

\author{
Vimaladewi Lukito, Irawan Mangunatmadja, Antonius H. Pudjiadi, Tatang M. Puspandjono \\ Departemen Ilmu Kesehatan Anak, RS Dr Cipto Mangunkusumo, Fakultas Kedokteran Universitas \\ Indonesia, Jakarta
}

\begin{abstract}
Plasmaferesis atau plasma exchange merupakan salah satu pilihan terapi bagi sindrom Guillain-Barre berat. Beberapa penelitian menunjukkan bahwa plasmaferesis dan imunoglobulin intravena (IVIg) sebagai terapi sindrom Guillain-Barre memiliki efektivitas yang sama, namun penggunaan plasmaferesis pada pasien anak lebih jarang dilakukan karena membutuhkan peralatan dan persiapan yang lebih kompleks. Tujuan dari laporan kasus untuk melaporkan terapi sindrom Guillain-Barre berat dengan menggunakan plasmaferesis pada pasien anak. Seorang anak perempuan usia 10 tahun dirawat di RSUPN. Dr. Cipto Mangunkusumo dengan diagnosis sindrom Guillain-Barre. Pada hari kedua perawatan pasien mengalami paralisis otot pernafasan sehingga pernafasan harus dibantu dengan ventilasi mekanik. Faktor ekonomi dan ketersediaan alat menyebabkan plasmaferesis dipilih sebagai terapi, dibandingkan dengan pengobatan IVIg. Plasmaferesis dilakukan empat kali dalam waktu satu minggu dengan menggunakan fraksi protein. Efek samping plasmaferesis berupa hipotensi dan sepsis yang ditangani dengan pemberian cairan dan antibiotik. Fungsi motorik pasien berangsur membaik dalam waktu satu minggu. Ventilasi mekanik dilepas setelah duapuluh enam hari dan pasien dipulangkan setelah dua bulan perawatan. Plasmaferesis dan IVIg memiliki efektifitas yang sama sebagai terapi sindrom Guillain-Barre berat. Keputusan untuk memilih salah satu terapi tersebut berdasarkan pada keadaan klinis pasien, sistem penunjang, dan kemampuan ekonomi orang tua pasien. (Sari Pediatri 2010;11(6):448-55).
\end{abstract}

Kata kunci: sindrom Guillain-Barre, plasmaferesis, plasma exchange

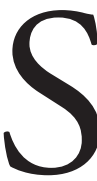
indrom Guillain-Barre (SGB) merupakan paralisis neuropati perifer yang bersifat ascending, progresif dan berhubungan dengan proses autoimun. Secara klinis, kejadian SGB sering didahului oleh infeksi akut non spesifik sebelumnya, seperti

Alamat korespondensi:

Dr. Irawan Mangunatmadja, Sp.A(K). Divisi Neurologi Departemen Ilmu Kesehatan Anak Fakultas Kedokteran Universitas Indonesia, Jl. Salemba Raya No.6, Jakarta 10430 Tel 62-21-3149161, Fax 62-21-3149161 infeksi saluran nafas atau infeksi saluran cerna. Gejala pada SGB terutama berupa kelemahan motorik dan areflexia namun juga dapat meliputi kelainan sensorik, otonom, dan batang otak. ${ }^{1,2}$ Insidens pada anak berkisar antara $0,5-1,5$ per 100,000 anak sakit dan merupakan penyebab paralisis motorik akut yang paling sering ditemukan. ${ }^{3-5}$ Prognosis SGB pada umumnya baik, namun pada beberapa kasus berat dapat menyebabkan kematian yang disebabkan oleh gagal nafas.

Plasmaferesis atau plasma exchange merupakan terapi yang pertama kali terbukti efektif pada kasus 
SGB berat. Perbaikan klinis pasien nampak nyata dalam kemampuan berjalan tanpa dibantu, waktu penggunaan ventilasi mekanik lebih singkat, dan gejala sisa lebih ringan. ${ }^{6}$ Pada anak yang menderita SGB, plasmaferesis jarang dilakukan karena prosedur ini membutuhkan persiapan yang lebih kompleks seperti unit perawatan intensif (ICU), akses vena sentral dan mesin plasmaferesis. Selain plasmaferesis, hanya intravenous immunoglobulin (IVIg) yang terbukti efektif dalam mengurangi kegawatan dan memperpendek perjalanan penyakit. ${ }^{1,5,6}$

Tujuan penulisan naskah kasus berbasis bukti, untuk melaporkan terapi SGB berat pada anak dengan menggunakan plasmaferesis dan menelaah lebih lanjut perbandingan antara terapi plasmaferesis dan IVIg pada pasien SGB.

\section{Kasus}

DR, anak perempuan usia 10 tahun datang ke Rumah Sakit Cipto Mangunkusumo (RSCM) dengan keluhan kesemutan p ada kedua kaki dan nyeri di punggung. Keluhan tersebut dirasakan sejak empat hari sebelum masuk rumah sakit. Kesemutan diikuti dengan kelemahan pada kedua tungkai bawah yang menjalar ke tungkai atas hingga pasien tidak dapat berdiri disertai dengan mengompol. Dari riwayat penyakit sebelumnya didapatkan dua minggu sebelum masuk rumah sakit pasien mengalami batuk, pilek, dan demam namun tidak tinggi. Pada pemeriksaan fisis didapatkan tanda vital dalam batas normal, dengan penurunan kekuatan motorik di kedua tungkai bawah disertai dengan hilangnya refleks tendon di kedua ekstremitas bawah. Pemeriksaan laboratorium darah lengkap, elektrolit dan kadar gula darah menunjukkan hasil yang normal. Diagnosis klinis ditegakkan SGB dan dirawat di bangsal anak RSCM.

Dalam duapuluh empat jam masa perawatan, kelemahan di kedua tungkai menjalar ke atas sehingga pasien mengalami kelemahan di kedua tangan dan kesulitan bernafas. Pasien kemudian dipindahkan ke ICU anak dan pernafasan dibantu dengan ventilasi mekanik. Saat itu dipertimbangkan pemberian IVIg sebagai terapi SGB, namun karena masalah biaya dan IVIg tidak ditanggung dalam program kesehatan nasional, terapi IVIg terpaksa ditunda. Sebagai pilihan pengobatan lain, pemberian plasmaferesis dilakukan pada pasien sebagai terapi alternatif SGB. Satu minggu setelah pasien dirawat, plasmaferesis dilakukan dengan menggunakan fraksi protein Plasmanate $^{\circledR}, 50 \mathrm{ml} / \mathrm{kg} /$ kali, empat kali dalam kurun waktu satu minggu. Pada prosedur plasmaferesis yang kedua dan ketiga pasien mengalami hipotensi yang segera diatasi dengan pemberian cairan intravena. Pada hari kesebelas perawatan setelah plasmaferesis kedua, pasien menderita sepsis. Biakan darah dan urin menunjukkan kuman Acinetobacter sp dan kadar serum procalcitonin 3.39 (kadar normal $<0.5 \mathrm{ng} / \mathrm{mL}$ ). Pemeriksaan cairan serebrospinal dari pungsi lumbal menunjukkan hasil normal, dan tidak terdapat disosiasi sitologi-albumin. Pasien juga diberi Ceftazidime $75 \mathrm{mg} / \mathrm{kg} / \mathrm{h}$ ari, intravena dan Amikasin $13 \mathrm{mg} / \mathrm{kg} / \mathrm{hari}$, intravena. Kedua antibiotik kemudian diganti dengan Meropenem 100mg/kg/hari, IV sesuai dengan hasil uji sensitifitas biakan.

Satu minggu setelah plasmaferesis dimulai, fungsi motorik pasien berangsur membaik. Ventilasi mekanik dilepas setelah duapuluh enam hari dan pasien mulai dapat menggenggam obyek pada kedua tangan. Nutrisi diberikan melalui selang nasogastrik dan fisioterapi dilakukan secara berkala untuk melatih otot. Pasien dipulangkan setelah dua bulan perawatan dan secara teratur pasien melakukan fisioterapi dan kontrol pada Poliklinik Neurologi Anak RSCM. Saat ini pasien sudah dapat duduk dengan disangga dan dapat makan makanan padat.

\section{Masalah klinis}

Pengalaman klinis terhadap penggunaan plasmaferesis sebagai terapi SGB pada anak masih jarang dilakukan terutama di Indonesia. Pemilihan plasmaferesis sebagai terapi pada SGB yang berat pada kasus ini berdasar pada ketersediaan cairan pengganti plasma yang dijamin oleh program kesehatan, dan pasien dirawat di ruang ICU sehingga monitoring ketat dapat dilakukan secara berkala. Untuk itu diformulasikan pertanyaan klinis sebagai berikut: "Pada anak yang menderita sindrom Guillain-Barre berat, apakah terapi plasmaferesis efektif apabila dibandingkan dengan pemberian IVIg dan apa yang menjadi pertimbangan dalam pemilihan terapi?”

\section{Strategi penelusuran}

Prosedur pencarian literatur untuk menjawab pertanyaan tersebut, telah dilakukan penelusuran kepustakaan 
secara online dengan mempergunakan instrumen pencari Pubmed, Cochrane Library, Google, dan Yahoo. Kata kunci yang dipergunakan adalah "guillain-barre syndrome", "plasmapheresis", "plasma exchange" dan "intravenous immunoglobulin" dengan menggunakan batasan (limit), publikasi bahasa Inggris, dilakukan pada manusia, publikasi dalam duapuluh tahun terakhir, serta kata kunci terdapat pada judul atau abstrak.

Dengan metode penelusuran tersebut, pada awalnya didapatkan 52 artikel yang memenuhi kriteria tersebut. Setelah penelusuran lebih lanjut, didapatkan 14 artikel yang relevan dengan masalah, yaitu sebanyak dua studi retrospektif, dua artikel uji klinis, tiga artikel uji klinis acak, lima artikel telaah, dan dua artikel telaah sistematik. Levels of evidence ditentukan berdasarkan klasifikasi yang dikeluarkan oleh Oxford Centre for Evidence-based Medicine Levels of Evidence. ${ }^{7}$

\section{Hasil penelusuran}

Bril V dkk ${ }^{8}$ pada tahun 1996 melakukan percobaan pendahuluan yang membandingkan terapi plasmaferesis dengan imunoglobulin pada pasien SGB dewasa. Uji klinis acak dilakukan pada limapuluh pasien dengan hasil waktu untuk mencapai perbaikan dalam waktu 1 bulan nampak lebih unggul pada kelompok IVIg namun tidak bermakna secara statistik (61\% pada kelompok plasmaferesis dan 69\% pada kelompok IVIg). Rerata waktu perbaikan 1 skala disabilitas (Tabel 1) selama 14 hari pada kelompok IVIg dan 16,5 hari pada kelompok plasmaferesis (Level of evidence: 1b). Hasil serupa juga didapat dari penelitian uji klinis acak yang dilakukan oleh Sandoglobulin Guillain-Barre Syndrome trial group ${ }^{9}$ pada tahun 1997. Kelompok tersebut melakukan uji klinis acak multisenter di sebelas negara dengan jumlah sampel akhir 379 pasien. Mereka mendapatkan bahwa perbaikan dalam waktu satu bulan, waktu lepas dari ventilator dan keluar dari rumah sakit, tidak berbeda bermakna pada kedua kelompok terapi. Kedua terapi memiliki efektifitas yang sama bila dilakukan dalam waktu dua minggu setelah onset gejala neuropati muncul. Mereka juga untuk pertama kalinya menyelidiki terapi gabungan antara plasmaferesis dan IVIg pada kasus SGB dengan hasil bahwa terapi gabungan tidak lebih superior dibanding dengan terapi terpisah (Level of evidence: $1 b$ ).

Sebuah telaah yang dilakukan oleh Winer JB $\mathrm{dkk}^{6}$ pada tahun 2002 mempelajari enam uji klinis acak
( $\mathrm{n}=649$ ) menilai efektivitas plasmaferesis dibandingkan dengan terapi suportif. Secara keseluruhan didapatkan jumlah pasien yang mengalami kemajuan klinis yang signifikan lebih banyak pada kelompok yang menerima plasmaferesis (RR: 1.7 95\%CI: 1.42-2.03, $\mathrm{p}<0.00001$ ) dibandingkan kelompok terapi suportif. Winer juga mempelajari tiga uji klinis acak mengenai peran IVIg pada SGB dibandingkan dengan plasmaferesis $(n=398)$ dengan hasil tidak didapatkan perbedaan yang bermakna antara IVIg dan plasmaferesis dalam hal kemajuan klinis dan mortalitas pasien SGB (Level of evidence: 1a).

Pada tahun 2004 Dada MA dan Kaplan AA ${ }^{10}$ melakukan penelitian retrospektif terhadap 11 pasien SGB berat yang membutuhkan plasmaferesis. Pasien SGB yang gagal dengan terapi IVIg dan akhirnya diberi plasmaferesis juga turut diidentifikasi. Mereka menyimpulkan pada pasien SGB berat tipe axonal, pengobatan plasmaferesis lebih unggul dibandingkan dengan IVIg sehingga pada SGB tipe axonal mereka lebih menganjurkan pemberian plasmaferesis. Terbatasnya jumlah sampel pada penelitian Dada MA dkk maka dianjurkan suatu studi prospektif dalam skala yang lebih besar untuk meneliti rekomendasi tersebut lebih lanjut. (Level of evidence: $2 b$ )

Telaah yang dilakukan oleh Harel dan Shoenfeld ${ }^{11}$ tahun 2005 terhadap tiga uji klinis acak $(\mathrm{n}=583)$, satu uji klinis $(\mathrm{n}=24)$ dan satu studi retrospektif $(\mathrm{n}=10)$, mendapatkan dalam dua studi IVIg lebih superior dibanding plasmaferesis dalam hal perbaikan keadaan klinis pasien. Satu studi menunjukkan plasmaferesis lebih superior dibanding IVIg dan dua studi tidak menunjukkan perbedaan bermakna antara kedua terapi tersebut (Level of evidence: 2a).

Hughes RAC dkk ${ }^{12}$ pada tahun 2007 melakukan suatu telaah sistematik $(n=697)$ terhadap lima uji klinis acak yang menyelidiki plasmaferesis dan IVIg pada kasus SGB. Dosis IVIg yang digunakan berkisar antara $0,4-0,5 \mathrm{~g} / \mathrm{kg} /$ hari selama $4-5$ hari sedangkan dosis plasmaferesis $200-250 \mathrm{ml} / \mathrm{kg}$ dalam beberapa kali prosedur selama 7-14 hari. Perbaikan klinis yang didapat dalam waktu empat minggu pada kelompok plasmaferesis 53\% dibanding dengan kelompok IVIg $58,2 \%$ (RR 1,09 95\%CI 0,94-1,27). Mortalitas pada kedua kelompok tidak berbeda secara bermakna, $3,1 \%$ pada plasmaferesis dan 2,4\% pada IVIg (RR 0,78 95\%CI 0,31-1,95). Angka kekambuhan pada kelompok plasmaferesis $6 \%$ pada plasmaferesis dan 5,2\% pada IVIg (RR 0,89 95\%CI 0,42-1,89). 
Jadi secara umum dapat disimpulkan bahwa tidak terdapat perbedaan yang bermakna antara kelompok plasmaferesis dan IVIg (level of evidence: 1a).

Suatu meta analisis yang juga dilakukan oleh Hughes RAC $\mathrm{dkk}^{13}$ melalui Cochrane database systematic review pada tahun $2006(\mathrm{n}=536)$ yang mencakup lima uji klinis acak, mendapatkan hasil pada empat uji klinis acak $(n=495)$ angka putus terapi pada kelompok IVIg lebih rendah 14\% dibanding kelompok plasmaferesis (95\% CI 0,05-0,36). Perbedaan yang signifikan ini didasarkan pada prosedur pemberian IVIg yang lebih mudah dibandingkan dengan plasmaferesis. Dua uji klinis acak menyimpulkan bahwa efek samping lebih banyak didapatkan pada plasmaferesis, sedangkan satu uji klinis acak menyatakan efek samping lebih banyak terdapat pada kelompok IVIg dan pada dua studi acak lainnya tidak didapatkan perbedaan bermakna dalam hal efek samping. Secara garis besar dikatakan bahwa plasmaferesis dan IVIg memiliki efektifitas yang ekuivalen dalam mempercepat penyembuhan SGB (Level of evidence: 1a).

Dari hasil penelusuran didapatkan dua artikel yang membahas tentang plasmaferesis dan IVIg dari sisi farmakoekonomi. Pada tahun 1999 Nagpal S dkk ${ }^{14}$ melakukan telaah dari beberapa literatur dan melakukan cost-effectiveness analysis terhadap plasmaferesis dan IVIg pada pasien SGB ( $\mathrm{n}=526)$. Mereka mendapatkan bahwa prosedur plasmaferesis di Kanada lebih murah sekitar \$4.000 dibandingkan dengan IVIg (level of evidence: 1b). Hal ini berlawanan dengan penelitian yang dilakukan oleh Tsai CP dkk ${ }^{15}$ pada tahun 2007 di Taiwan, yang melakukan studi retrospektif terhadap 24 pasien SGB. Mereka mengatakan bahwa walaupun harga obat IVIg lebih mahal dibandingkan plasmaferesis, namun secara keseluruhan terapi dengan IVIg lebih murah $(p=0,057)$. Hal ini disebabkan karena pada prosedur dengan IVIg, didapatkan komplikasi yang lebih rendah, proses prosedur yang lebih murah, dan lama tinggal di rumah sakit yang lebih singkat (Level of evidence: $2 b$ ).

\section{Pembahasan}

Sindrom Guillain Barre bermanifestasi dalam bentuk paralisis motorik yang simetris, dengan atau tanpa gangguan sensorik dan otonom. Fase progresif dari SGB berlangsung dalam beberapa hari hingga empat minggu dan diikuti dengan fase plateau, saat gejala berada dalam keadaan persisten sebelum diakhiri dengan masa resolusi dari gejala yang lamanya bervariasi. Diagnosis dari SGB berdasarkan gambaran klinis, pemeriksaan elektrodiagnostik (EMG), dan analisis cairan serebro spinal. ${ }^{1,2}$ Berdasarkan gambaran klinis dan elektrofisiologi, SGB dibagi dalam beberapa tipe seperti yang tertera pada Tabel 1 .

Tabel 1. Subtipe dari sindrom Guillain-Barre

- Acute inflammatory demyelinating polyradiculoneuropathy (AIDP)

- Acute motor axonal neuropathy (AMAN)

- Acute motor sensory axonal neuropathy (AMSAN)

- Miller Fisher syndrome

- Acute panautonomic neuropathy
Mediasi oleh antibodi, dipicu oleh infeksi virus atau bakteri sebelumnya, gambaran elektrofisiologi berupa demielinisasi, remielinisasi muncul setelah reaksi imun berakhir, merupakan tipe SGB yang sering dijumpai di Eropa dan Amerika.

Bentuk murni dari neuropathy axonal, 67\% pasien seropositif untuk Campylobacteriosis, elektrofisiologi menunjukkan absen/turunnya saraf motorik dan saraf sensorik, penyembuhan lebih cepat, sering terjadi pada anak, merupakan tipe SGB yang sering di Cina dan Jepang.

Degenerasi mielin dari serabut saraf motorik dan sensorik, mirip dengan AMAN hanya tipe ini juga mempengaruhi sensorik, seringkali terdapat pada dewasa. Merupakan kelainan yang jarang dijumpai, berupa trias ataxia, areflexia dan oftalmoplegia, dapat terjadi gangguan proprioseptif, resolusi dalam waktu 1-3 bulan.

Varian yang paling jarang dari SGB, mempengaruhi sistim simpatis dan parasimpatis, gangguan kardiovaskular (hipotensi, takikardi, hipertensi, disaritmia), gangguan penglihatan berupa pandangan kabur, kekeringan pada mata dan anhidrosis, penyembuhan bertahap dan tidak sempurna, sering dijumpai juga gangguan sensorik.

Sari Pediatri, Vol. 11, No. 6, April 2010 
Pada pasien dengan SGB ringan, diberikan terapi suportif dengan pemantauan ketat dan persiapan bila pasien secara klinis mengalami perburukan. Plasmaferesis diindikasikan pada kasus yang nonambulatory, atau yang penyakitnya berlangsung secara agresif. Derajat penyakit SGB didasarkan pada skala disabilitas dari Hughes (Tabel 2). ${ }^{12}$ Pada SGB berat, pasien memiliki skala $\geq 4$.

Tabel 2. Skala disabilitas sindrom Guillain-Barre menurut Hughes

\begin{tabular}{ll}
\hline 0 & Sehat \\
1 & $\begin{array}{l}\text { Gejala minor dari neuropati, namun dapat } \\
\text { melakukan pekerjaan manual }\end{array}$ \\
2 & $\begin{array}{l}\text { Dapat berjalan tanpa bantuan tongkat, namun } \\
\text { tidak dapat melakukan pekerjaan manual }\end{array}$ \\
3 & $\begin{array}{l}\text { Dapat berjalan dengan bantuan tongkat atau } \\
\text { alat penunjang }\end{array}$ \\
4 & $\begin{array}{l}\text { Kegiatan terbatas di tempat tidur/kursi (bed/ } \\
\text { chair bound) }\end{array}$ \\
5 & $\begin{array}{l}\text { Membutuhkan bantuan ventilasi } \\
6\end{array}$ \\
Kematian
\end{tabular}

Penggunaan plasmaferesis sebagai terapi pada SGB pertama kali dilaporkan pada tahun 1978 yang kemudian mengarah kepada enam uji klinis acak yang membandingkan antara plasmaferesis dengan terapi suportif. Hasil yang didapat adalah terapi plasmaferesis terbukti efektif, sehingga pada tahun 1986 terapi plasma feresis direkomendasikan pada kasus SGB berat. ${ }^{12,16}$ Plasmaferesis dilakukan 3-5 kali dalam kurun waktu 5-10 hari, dengan dosis 40-55 ml/kg/kali. Bahan pengganti plasma yang digunakan adalah albumin atau fresh frozen plasma (FFP). ${ }^{12,16,17}$ Pada proses plasmaferesis, plasma dipisahkan dalam mesin dialisis dan kemudian digantikan dengan albumin atau FFP, dengan demikian antigen asing yang ada dalam plasma pasien dapat dibuang. ${ }^{17,18}$ Kasus kami menggunakan Plasmanate $^{\circledR}$ yang merupakan fraksi protein plasma sebagai cairan pengganti. Prosedur plasmaferesis pada pasien dilakukan sesuai dengan rekomendasi dari literatur, empat kali dalam waktu satu minggu.

Pemberian IVIg diduga dapat menetralisasi antibodi mielin yang beredar dengan berperan sebagai antibodi anti-idiotipik, menurunkan sitokin proinflammatory dan menghadang kaskade komplemen serta mempercepat proses mielinisasi. ${ }^{11,19}$ Dosis yang diberikan $0,4-0,5 \mathrm{gram} / \mathrm{kg} / \mathrm{kali}$ selama $4-5$ hari berturut-turut dengan total dosis 2 gram $/ \mathrm{kg}$. ${ }^{8,11,13,20}$ Bila dibandingkan dengan plasmaferesis, IVIg memiliki beberapa kelebihan yaitu sediaan lebih mudah didapat dan pemberiannya tidak memerlukan alat khusus. ${ }^{6,21}$

Pada plasmaferesis efek samping yang sering ditemukan adalah hipotensi, pneumonia, trombosis, sepsis, dan gangguan hemodinamik. ${ }^{12,16,17,22}$ Pada kasus kami dijumpai efek samping dari plasmaferesis berupa hipotensi saat prosedur berlangsung dan sepsis yang terjadi pada minggu kedua. Kedua efek samping tersebut dapat diatasi dengan pemberian cairan dan antibiotik. Selama dilakukan plasmaferesis kondisi pasien perlu dimonitor dengan ketat termasuk pemeriksaan laboratorium yang diperlukan untuk meminimalisasi efek samping yang dapat terjadi. Pemberian IVIg dapat menimbulkan efek samping berupa nyeri kepala, ruam, demam, mialgia dan peningkatan kadar serum alanine aminotransferase. Syok anafilaktik dapat pula terjadi sebagai efek samping yang berat dari pemberian IVIg. ${ }^{11,13,23}$

Waktu yang dibutuhkan untuk melepas ventilator pada kasus kami, 26 hari, sesuai dengan hasil penelitian yang dilakukan oleh Sandoglobulin Guillain-Barre syndrome trial group yaitu 29 hari pada kelompok plasmaferesis dan 26 hari pada kelompok IVIg. ${ }^{9}$

Secara garis besar berdasarkan penelitian yang ada, plamaferesis dan IVIg memiliki efektifitas yang sama sebagai terapi pada SGB berat. Di Kanada, harga IVIg yang mahal menyebabkan terapi ini menghabiskan biaya yang lebih besar dibandingkan dengan plasmaferesis, ${ }^{14}$ sedangkan di Amerika Serikat plasmaferesis menghabiskan biaya yang lebih besar. ${ }^{13}$ Di Taiwan, walaupun plasmaferesis menghabiskan biaya yang lebih besar namun prosedur tersebut ditanggung oleh program kesehatan nasional sedangkan IVIg tidak ditanggung oleh program kesehatan di negara tersebut. ${ }^{15}$ Pada kasus kami, IVIg tidak ditanggung oleh program kesehatan nasional, sedangkan cairan pengganti plasma dan prosedur plasmaferesis ditanggung oleh jaminan kesehatan, dengan demikian pada pasien ini diputuskan pemberian plasmaferesis sebagai terapi SGB.

\section{Kesimpulan}

Plasmaferesis dan IVIg terbukti memiliki efektifitas 
yang sama sebagai terapi untuk sindrom GuillainBarre berat. Keputusan untuk memilih salah satu terapi tersebut didasarkan pada kondisi pasien, sistem penunjang, dan latar belakang ekonomi orang tua pasien. Pada kasus kami plasmaferesis dipilih sebagai terapi SGB berdasarkan pertimbangan tersebut. Namun berdasarkan telaah dan pembahasan, IVIg tetap merupakan bentuk yang lebih sederhana dan lebih mudah dilakukan sebagai terapi pada SGB, sehingga bila memungkinkan terapi dengan IVIg layaknya dipertimbangkan lebih dahulu sebagai pilihan pertama. Setiap terapi memiliki keuntungan dan kerugian masing-masing, sehingga pilihan yang paling menguntungkan bagi pasien harus menjadi dasar untuk menentukan jenis terapi. Masih diperlukan penelitian tentang penggunaan plasmaferesis dan IVIg pada anak dengan sindrom Guillain-Barre dengan skala yang lebih besar mengingat penelitian tentang kedua terapi yang dilakukan pada anak-anak masih sedikit.

\section{Daftar Pustaka}

1. Kuwabara S. Guillain-Barre syndrome epidemiology, pathophysiology and management. Drugs 2010;64:597610.

2. Newswanger DL, Warren CR. Guillain-Barre syndrome. Am Fam Physician 2004;69:2405-10.

3. Korinthenberg R, Schessl J, Kirschner J. Clinical presentation and course of childhood GuillainBarre syndrome: A prospective multicentre study. Neuropediatrics 2007;38:10-7.

4. Koul RL, Alfutaisi A. Prospective study of children with Guillain-Barre syndrome. Indian J Pediatr 2008;75:78790.

5. Tseng BS, Markowitz JA. Guillain-Barre syndrome in childhood. Diunduh dari: http://www.emedicine.medscape. com/article/1180594. Diakses tanggal 9-9-2009.

6. Winer JB. Treatment of Guillain-Barre syndrome. Q J Med 2002;95:717-21.

7. Oxford centre of evidence-based medicine. Oxford centre for evidence-based medicine levels of evidence (March 2009). Diunduh dari: http://www.cebm.net/index. aspx? $=1025$.

8. Bril V, Ilse WK, Pearce R, Dhanani A, Sutton D, Kong K. Pilot trial of immunoglobulin versus plasma exchange in patients with Guillain-Barre syndrome. Neurology 1996;46:100-3.
9. Plasma Exchange/Sandoglobulin Guillain-Barre Syndrome Trial Group. Randomised trial of plasma exchange, intravenous immunoglobulin, and combined treatments in Guillain-Barre syndrome. Lancet 1997;349:225-30.

10. Dada MA, Kaplan AA. Plasmapheresis treatment in Guillain-Barre syndrome: Potential benefit over IVIg in patients with axonal involvement. Ther Apher Dial. 2004;8:409-12.

11. Harel M, Shoenfeld Y. Intravenous Immunoglobulin and Guillain-Barré Syndrome . Clin Rev Allergy Immunol 2005;29:281-7.

12. Hughes RAC, Swan AV, Raphael J, Annane D, Van Koningsveld R, Van Doorn PA. Immunotherapy for Guillain-Barre syndrome: a systematic review. Brain 2007; 130:2245-57.

13. Hughes RAC, Raphael J, Swan AV, Van Doorn PA. Intravenous immunoglobulin for Guillain-Barre syndrome. Cochrane Database of Systematic Reviews 2006

14. Nagpal S, Benstead T, Shumak K, Rock G, Brown M, Anderson D. Treatment of Guillain-Barre syndrome: A cost-effectiveness analysis. J Clin Apher 1999;14:10713.

15. Tsai CP, Wang KC, Liu CY, Sheng WY, Lee TC. Pharmacoeconomics of therapy for GuillainBarre syndrome: plasma exchange and intravenous immunoglobulin. J Clin Neurosci 2007;14:625-9.

16. Raphael JC, Chevret S, Hughes RAC, Annane D. Plasma exchange for Guillain-Barre syndrome (Review). Cochrane Database of Systematic Review 2002

17. Lehmann HC, Hartung HP, Hetzel GR, Stuve O, Kieseier BC. Plasma exchange in neuroimmunological disorders. Arch Neurol 2006;63:1066-71.

18. National Institute of Neurological Disorders and Stroke. Guillain-Barre fact sheet. Diunduh dari: http://www.ninds. nih.gov/disorders/gbs/detail_gbs.htm. Diakses tanggal 2-42010.

19. Miller AC, Rashid RM, Sinert RH. Guillain-Barre syndrome. Diunduh dari: http://emedicine.medscape.com/ article/792008.Diakses tanggal 9-9-2009.

20. Tasdemir HA, Dilber C, Kanber Y, Uysal S. Intravenous immunoglobulin for Guillain-Barre syndrome: How effective? J Child Neurol 2006;21:972-4.

21. Dawson WB, Phillips LH. A comparison between IVIg and plasma exchange in Guillain-Barre syndrome: A review and decision analysis of the two treatment modalities. Clin Neuropharmacol 1995;18:377-90.

22. Yeh JH, Chen WH, Chiu HC. Complication of double- 
Vimaladewi Lukito dkk: Plasmaferesis sebagai terapi SGB berat pada anak

plasmapheresis. Transfusion. 2004;44:1621-5.

23. Dalakas MC. Intravenous immunoglobulin in autoimmune neuromuscular diseases. JAMA 2004; $291: 2367-75$. 


\section{Lampiran}

Tabel 3. Penelitian yang membandingkan plasmaferesis dengan imunoglobulin intravena

\begin{tabular}{|c|c|c|c|c|}
\hline Studi & Design & Peserta & Terapi & Hasil \\
\hline Bril dkk, 1996 & $\begin{array}{l}\text { Uji klinis acak, } \\
\text { single centre }\end{array}$ & $\begin{array}{l}\mathrm{N}=50 \\
\text { Dewasa }\end{array}$ & $\begin{array}{l}\text { IVIg } 0.5 \mathrm{~g} / \mathrm{kg} / \mathrm{hari} \\
\text { selama } 4 \text { hari } v s \\
\text { plasmaferesis } 40-50 \mathrm{ml} / \\
\mathrm{kg} / \text { hari selama } 5 \text { hari }\end{array}$ & $\begin{array}{l}\text { Tidak ada perbedaan ber- } \\
\text { makna pada beberapa luaran }\end{array}$ \\
\hline Diener dkk, 2001 & $\begin{array}{l}\text { Uji klinis acak, } \\
\text { Multisenter }\end{array}$ & $\begin{array}{l}\mathrm{N}=67 \\
\text { Dewasa dan } \\
\text { anak }\end{array}$ & $\begin{array}{l}\text { IVIg } 0.4 \mathrm{~g} / \mathrm{kg} / \mathrm{hari} \\
\text { selama } 5 \text { hari } v \text { s plas- } \\
\text { maferesis } 40-50 \mathrm{ml} / \\
\text { kg sebanyak } 5 x \text { dalam } \\
\text { waktu } 14 \text { hari }\end{array}$ & $\begin{array}{l}\text { Tidak ada perbedaan ber- } \\
\text { makna pada tingkat kemaju- } \\
\text { an } \geq 1 \text { skala disabilitas setelah } \\
4 \text { minggu }\end{array}$ \\
\hline Nomura dkk., 2000 & $\begin{array}{l}\text { Uji klinis acak, } \\
\text { multisenter }\end{array}$ & $\begin{array}{l}\mathrm{N}=47 \\
\text { Dewasa }\end{array}$ & $\begin{array}{l}\text { IVIg } 0.4 \mathrm{~g} / \mathrm{kg} / \text { hari } \\
\text { selama } 5 \text { hari } v s \\
\text { plasmaferesis } 200- \\
250 \mathrm{ml} / \mathrm{kg} \text { (total) } \\
\text { sebanyak } 7 \mathrm{x} \text { dalam } \\
\text { waktu } 4 \text { minggu }\end{array}$ & $\begin{array}{l}\text { Tidak ada perbedaan ber- } \\
\text { makna pada beberapa luaran }\end{array}$ \\
\hline $\begin{array}{l}\text { Plasma exchange/ } \\
\text { Sandoglobulin Guillain- } \\
\text { Barre Syndrome Trial } \\
\text { Group, } 1997\end{array}$ & $\begin{array}{l}\text { Uji klinis acak, } \\
\text { multinasional, } \\
\text { multisenter }\end{array}$ & $\begin{array}{l}\mathrm{N}=383 \\
\text { Dewasa }\end{array}$ & $\begin{array}{l}\text { IVIg } 0.4 \mathrm{~g} / \mathrm{kg} / \text { hari } \\
\text { selama } 5 \text { hari } v \text { s plas- } \\
\text { maferesis } 250 \mathrm{ml} / \mathrm{kg} \\
\text { (total) selama } 8-13 \text { hari } \\
\text { vs plasmaferesis diikuti } \\
\text { dengan IVIg }\end{array}$ & $\begin{array}{l}\text { Tidak ada perbedaan ber- } \\
\text { makna pada tingkat kema- } \\
\text { juan setelah } 4 \text { minggu }\end{array}$ \\
\hline $\begin{array}{l}\text { Van der Meche dkk, } \\
1992\end{array}$ & $\begin{array}{l}\text { Uji klinis acak, } \\
\text { multisenter }\end{array}$ & $\begin{array}{l}\mathrm{N}=150 \\
\text { Dewasa dan } \\
\text { anak }\end{array}$ & $\begin{array}{l}\text { IVIg } 0.4 \mathrm{~g} / \mathrm{kg} / \mathrm{hari} \\
\text { selama } 5 \text { hari } v \text { s } \\
\text { plasmaferesis } 200- \\
250 \mathrm{ml} / \mathrm{kg} \text { selama } 7-14 \\
\text { hari }\end{array}$ & $\begin{array}{l}\text { Tingkat kemajuan } \geq 1 \text { skala } \\
\text { disabilitas sebesar } 53 \% \text { pada } \\
\text { kelompok IVIg vs } 34 \% \text { pada } \\
\text { kelompok plasmaferesis }\end{array}$ \\
\hline
\end{tabular}

